
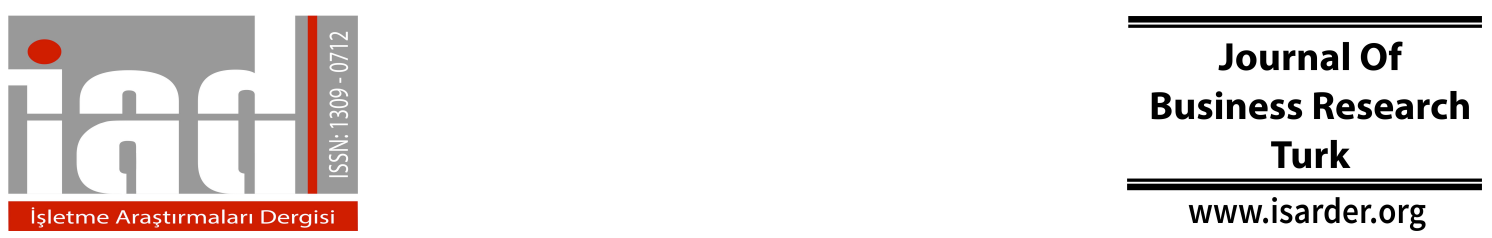

\title{
Causality between Corporate Governance and Firm Performance: Evidence from Borsa Istanbul (BIST)
}

\author{
Levent ATAÜNAL \\ İstanbul Aydın University \\ İstanbul, Turkey \\ leventataunal@aydin.edu.tr
}

\author{
Asli AYBARS 1 \\ Marmara University \\ İstanbul, Turkey \\ asli.aybars@marmara.edu.tr
}

\begin{abstract}
Due to increasing pace of globalization and recent corporate scandals, corporate governance arrangements have attracted attention and become an area of discussion. Besides securing interests of shareholders, it is also proposed that corporate governance practices enhance shareholders' value. Based on a data set from Borsa Istanbul (BIST) and associated BIST Corporate Governance Index for the period between 2007 and 2015 , this study attempts to evaluate whether market and operating performances of firms are affected from the level of adopted corporate governance practices. The study also addresses the issue of causality through systems equations constructed with selected instrumental variables. The findings revealed that corporate governance rating positively influenced stock market performance which was measured by Tobin's Q, and operating performance which was measured by return on assets. The study also found that the corporate governance sub-provisions of shareholders, public disclosure/ transparency and stakeholders had positive impact on market performance, while board structure was irrelevant.
\end{abstract}

Keywords: Corporate governance, firm performance, causality, emerging market, Tobin's Q

\section{Introduction}

The purpose of corporate governance is to enhance reliability, transparency, and accountability which are essential elements for nurturing investment environment and financial stability. Corporate governance policy defines relationships among management, board, shareholders, and other stakeholders. Today's globalized financial setting enables companies to access financing from a large pool of investors. Effective corporate governance will ensure the protection of shareholders' rights. It will ease finding investors, and eventually result in decreased cost of capital. If companies are willing to attract global capital, their corporate governance arrangements must be convincing to the international investors.

\footnotetext{
${ }^{1}$ Corresponding Author
} 
Corporate governance structures disclose and prevent potential agency problems as well. Agency problems arise when managers do not aim maximizing shareholders' value. A principal element of corporate governance is the alignment of shareholders' interests with the interests of agents (managers) appointed to run the firm (Lehmann and Weigard, 2000). Stock ownership of board members is a common practice in achieving this alignment and it is shown to be positively correlated with operating performance (Bhagat and Bolton, 2008).

As corporate governance is expected to decrease agency costs and cost of capital of the firm, there is a widespread belief that a better corporate governance arrangement translates into higher shareholder return. Current expansion of corporate governance rules largely stems from this conviction. Institutional investors are willing to pay significant premiums for well-governed companies. Then, the value of a firm becomes dependent on governance practices at least as much as on financial issues (Drobetz et al. 2004). Various studies confirmed this common belief (Gompers et al., 2003; Bhagat and Bolton, 2008; Black et al. 2006a; Black et al. 2006b; Brown and Caylor, 2006; Bauer et al. 2008; Sylva and Leal, 2005), though some researches challenged it (Bebchuck et al.2009).

In line with the expansion of global awareness on corporate governance, Borsa Istanbul (BIST) established an index to encourage firms' adoption of corporate governance principles, which is expected to result in a more transparent and efficient financial market. The index aims to measure the return performances of companies included in the index. Only firms with ratings above a certain level are included in the index. Corporate governance ratings are offered by the agencies, which are authorized by Capital Markets Board (CMB), upon the demand of the firm and are to be renewed each year. This study aimed to reveal the impact of those corporate governance ratings on firms' market and operating performances.

The rest of the paper is organized as follows. Section two reviews the prior studies on corporate governance and performance relationship, section three explains the data and methodology used in this study, section four presents the results of the study, and section five concludes.

\section{Literature review}

Majority of the prior studies in literature started with formulating a governance index. Then they attempted to rate the corporate governance structures in the firm with this index. For instance, Gompers et al. (2003) created a "Governance Index" to proxy for shareholder rights. They confirmed that stronger shareholder rights led to higher stock returns, higher firm value, higher profits, higher sales growth, lower capital expenditures, and fewer corporate acquisitions. Positive relationship between corporate governance rating and firm value is also verified by other studies (Drobetz et al.,2004; Bauer et al., 2008; Brown and Caylor, 2006).

An investment strategy that bought firms with high corporate governance ratings and shorted firms with low corporate governance ratings brought $12 \%$ abnormal return on an annual basis (Drobetz et al. 2004). Likewise, employing an overall governance index involving Japanese firms, Bauer et al. (2008) confirmed the superior performance of well-governed firms in comparison to weakly governed firms. Within the governance 
provisions they have selected, financial disclosure, shareholder rights, and remuneration were the major factors affecting stock price performance.

Brown and Caylor, (2006) utilized a governance index based on seven provisions to show that corporate governance positively impact firm value (which was proxied by Tobin's Q). Seven provisions utilized were mainly related to board structure: (1) Annual election of board members; (2) no poison pill or one approved by shareholders; (3) option re-pricing did not occur within the last three years; (4) average options granted in the past three years as a percentage of basic shares outstanding did not exceed $3 \%$; (5) all directors attended at least $75 \%$ of board meetings or had a valid excuse for nonattendance; (6) board guidelines are in each proxy statement; and (7) directors are subject to stock ownership guidelines.

Studies in other countries also delivered comparable results. Black et al. (2006b) confirmed that an overall corporate governance index was an important factor in explaining higher market value of Korean public companies. A study with the Russian firms documented the strong correlation between corporate governance and market value (Black et al. 2006a). These studies also disclosed the predictive power of subcomponents of these indices.

On the other hand, some corporate governance provisions are found to negatively affect firm performance. Bebchuck et al. (2009) discovered six governance provisions which were negatively correlated with firm value (measured by Tobin's Q and with stock returns). The six provisions they have identified were staggered boards (in which directors were divided into separate classes with each class being elected to overlapping terms), limits to shareholder bylaw amendments (A provision limiting shareholders' ability through majority vote to amend the corporate bylaws), poison pills, golden parachutes, and supermajority requirements for mergers and charter amendments. On the other hand, contrary to the common belief, the presence of large shareholders did not result in higher profitability (Lehmann and Weigand, 2000).

Different asset structures require different levels of corporate governance practices. A firm with higher proportion of intangible assets adopts stricter governance mechanisms to avoid misuse of these assets (Klapper and Love, 2002). The negative correlation between fixed assets proportion and governance should then result in higher Tobin's Q. Another endogenous factor is the difference in growth opportunities of firms. Firms with good growth opportunities generally need external financing. It is better for them to improve their governance mechanisms since better governance is likely to lower cost of capital.

Another important matter of dispute is whether the firm's governance structure affects informational efficiency of prices. In a recent study, Lee et al. (2015) revealed that informational efficiency of prices increases with the quality of corporate governance as effective corporate governance prompts timely disclosure of information. They suggested that better corporate governance increased shareholder wealth by enabling shareholders better evaluate the quality of management and the value of the firm. In their study, they measured corporate governance quality by means of 20 standards on board-related issues, six standards on audit-related issues, six standards on progressive practices, and one standard on director education. They estimated informational efficiency of prices using the model suggested by Hasbrouck (1993). In the Hasbrouck's model transaction prices consist of random-walk component which 
reflects all public information and the private information content, and transitory component which captures the non-informational portion of transaction prices (i.e. noise-trading, mispricing, and market frictions).

The OECD principles of corporate governance were initially endorsed in 1999 and were revised in 2004 to cope with the developments undergoing in both member and non-member countries. The second revision strengthened the 2004 version of the principles while maintaining the core values. The resulting principles were adopted on 8 July 2015 by OECD council and they were endorsed as G20/OECD Principles of Corporate Governance at G20 Leaders Summit in Antalya. The principles are organized under six chapters, namely; ensuring the basis for an effective corporate governance framework, the rights and equitable treatment of shareholders and key ownership functions, institutional investors, stock markets, and other intermediaries, the role of stakeholders, disclosure and transparency, and the responsibilities of the board (OECD, 2015). Even though there is no uniform and single model of corporate governance proposed, the principles provide guidance to improve the relationships among all stakeholders of the company and enhance legal, regulatory, and institutional framework. Each country is expected to establish its corporate governance practices in accordance with the specific conditions prevailing in the country. However; equality, transparency, accountability, and responsibility are considered to be the main categories of corporate governance (CMB, 2005). The Corporate Governance Principles of Turkey were first issued by the Capital Markets Board of Turkey (CMB) in 2003 and were later amended in 2005. Capital Markets Board's (CMB) Corporate Governance Principles are based on four main imperatives listed below:

Equality: Equal treatment of all shareholders;

Transparency: Ensuring clear, accurate and timely flow of information to the public;

Accountability: Presence of efficient internal control systems;

Responsibility: Abiding relevant rules and laws governing the conduct of relations with major stakeholders

In accordance with these imperatives, four sub-criteria are defined for rating, namely; shareholders, public disclosure and transparency, stakeholders, and board of directors. Weighted average of ratings in these areas leads into the final corporate governance score of the firm. Each sub-criterion is analyzed against a checklist for assessment.

Sub-criterion 1: Shareholders - 25\% weight in the overall rating

Sufficient measures must have been taken to facilitate the exercise of shareholders' statutory rights. There should be no discrimination among shareholders. All information required to facilitate exercise of shareholders' rights must be available to all shareholders in a complete, accurate, timely, and diligent manner. Majority shareholders should not be able to exploit their dominancy over minority shareholders. Minority shareholders' rights must be respected. Respect to voting rights is essential. Dividend policy must be clearly defined and disclosed to public. Dividend payments are made timely. No limitations should exist for transfer of shares.

Sub-criterion 2: Public Disclosure and Transparency - 25\% weight in the overall rating 
Firms are expected to be transparent to the investors and creditors. Disclosed information should be timely, accurate, complete, comprehensible, and easily accessible. Firms are expected to provide comprehensive information through their bilingual web-site. They should prepare and disclose financial statements and footnotes presenting exact financial status of the company. Firms' financial statements are required to be audited by an independent auditor.

\section{Sub-criterion 3: Stakeholders - 15\% weight in the overall rating}

Firms should have healthy relationship with all stakeholders. They should respect the rights of stakeholders that are protected by law, mutual arrangements and contracts. To maintain the long-lasting healthy relationship, firms must retain written procedures to handle the issues with the stakeholders. Human resource principles should be wellwritten and communicated. Complaints must be investigated and resolved without major delay.

Sub-criterion 4: Board of Directors - 35\% weight in the overall rating

The board of directors, which is the highest management body of the company, should balance the interests of shareholders and other stakeholders while aiming to increase shareholders' total value. Selected directors should be well-informed, diligent, and with sufficient background and expertise. Members of the board must be able to use their own free judgment, without any external influence. Therefore, the proportion of independent board members is an important factor. Independent board members supposedly act more objectively in the decision-making process. Committees of the board should be composed of and chaired by preferably independent members.

Borsa Istanbul (BIST) established BIST Corporate Governance Index on 31 August 2007 with only five companies to encourage listed firms to adopt corporate governance principles. The index aims to measure the price and return performances of listed companies which have minimum overall corporate governance rating of seven out of ten. Authorized agencies rate individual firms upon their request. Ratings are renewed each year. The number of the listed companies included in the index has currently reached to 49 (http://www.borsaistanbul.com).

The launch of the BIST corporate governance index and the increase in the number of firms included in the index resulted in a surge of researches on the link between corporate governance and firm performance. Corporate governance ratings facilitate measuring compliance of firms to these principles. Some of the recent studies on BIST are those of Erdoğan and Öztürk (2016), Kara et al. (2015), Kula and Baykut (2015), and Aydin and Ozcan (2015). Erdoğan and Öztürk (2016) documented a positive and significant association between corporate governance rating of 14 firms and the selected performance measure, net profit margin, for the 2009-2014 period. A similar relationship is also found in the study of Kara et al. (2015) in which corporate governance rating is shown to positively affect market to book ratio. Kula and Baykut (2015) also verified a positive association between rating and market value of 43 firms listed between 2007 and 2014. Yenice and Dölen (2013) demonstrated that this relationship was significant for the years 2009, 2010, and 2011 when the sample size was larger.

Contrarily, Aydin and Ozcan (2015) adopted a different methodology and investigated whether accounting ratios impact governance scores. They verified the 
insignificant impact of profitability on corporate governance rating for the period between 2008 and 2014. They justified their results with the limited number of firms listed on the index during the observation period. With multi-criteria decision analysis method, Ege et al. (2013) showed that quality of corporate governance was not reflected on the performance score. Event study analysis carried out by Sakarya (2011) detected a positive link between stock return and rating announcement. The majority of the previous studies proposed that corporate governance rating and performance are positively associated.

The growing empirical literature on corporate governance is limited with the country data and methodology used to rate firms' corporate governance. The impact of governance rating on performance may vary greatly on the methodology used and the variables chosen. Some of the prior studies attribute superior performance resulting from better governance practices to higher informational efficiency in the prices. However, higher informational efficiency may only be attributed to some of the subprovisions. For instance, stakeholders sub-provision cannot be expected to play any role on the informational efficiency. Thus corporate governance structures within the firm may also have direct effect on corporate performance, besides increasing shareholder wealth by enabling shareholders better evaluate the quality of management and the value of the firm. This study attempted to understand overall effect of corporate governance practices on market and operating performance of the firm. Unlike most of the previous studies in Turkey, this study:

- Excluded financial firms,

- Used panel structure and used a longer time span (2007-2015),

- Considered the possible endogeneity between corporate governance and firm performance.

\section{Data and methodology}

The sample of the study comprises 22 non-financial listed firms on BIST. Financial firms are deliberately excluded, not only because they have fundamentally different operating activities but also, including their governance structures, they are closely regulated. Period of analysis starts in year 2007 when some firms in the dataset started having corporate governance rating. The firms rated at least for four consecutive periods are admitted to the sample. Thus, data sample is not balanced. Both overall governance rating scores and sub-criteria rating scores are employed in the analysis. Corporate governance rating scores are collected through each firm's corporate governance rating report. Most of these ratings are carried out by a single rating agency. Although same methodology is adopted in these ratings, using rating scores mostly performed by a single rating agency augments the reliability of the empirical study.

Like some prior studies, Tobin's Q is used to measure market performance, and return on assets (ROA) is used to measure operating performance of the firm (Bhagat and Bolton, 2008; Bhagat et al. 2008; Silva and Leal 2005; Gompers et al.2003). Tobin's Q is estimated with the market value of assets divided by the book value of assets, where the market value of assets is computed as the book value of assets plus the market value of equity less book value of equity. ROA is estimated as operating income divided by total assets. Independent variables chosen are similar to suggested by Bhagat and Bolton (2008). 
Main variables used in the study are:

Dependent variables

MA_BA: Tobin's Q - proxy for Market Performance

EBIT_ASSETS: Return on Assets (ROA) - proxy for Operating Performance

Independent Variables

CGI_OVERALL: Overall Corporate Governance Rating - proxy for corporate governance of the firm

PUBLIC_SHARES: Proportion of shares that are floating in BIST - proxy for ownership structure

MARKET_LEVERAGE: total debt / market value of assets - proxy for capital structure Instrumental variables used in addition to lag values of independent variables

$\log$ (assets): logarithm of total assets - proxy for size

fixedassets_assets: tangibility - ratio of fixed or tangible assets in total assets of the firm

book_leverage - total debt divided by total assets

shareholder_return - (share price increase + dividends)/share price

Shareholders: rating in shareholders sub-provision of corporate governance report

Stakeholders: rating in stakeholders sub-provision of corporate governance rating report

Chosen instruments are expected to induce changes in explanatory variables but not in the dependent variable. All instruments are predicted to have some impact on the explanatory variables. Firm size, which is proxied with $\log$ (assets), is employed as an instrumental variable instead of being included on the right side of the equation.

Tangibility (fixedassets_assets) might have impact on market_leverage. Firms with higher proportion of fixed assets are expected to have higher financial leverage. Corporate governance sub-provisions are expected to have impact on overall corporate governance rating. However, as Bhagat and Bolton (2008) also pointed out, the choice of appropriate instruments is a challenging task. Almost any instrumental variable identified for an endogenous variable will possibly be related to at least another, and possibly more, endogenous variables. Thus, before deciding on instrumental variables of system equations, many alternate instruments are explored and tested. The instruments suggested above are chosen as the appropriate instruments after these trials.

\section{Results}

In Table 1, correlations between the sub-provisions of corporate governance ratings are given. Shareholders, public disclosure and transparency, and stakeholders are highly inter-correlated. On the other hand, board of directors seems to be rather independent from the other sub-provisions of corporate governance. 
Table 1: Pearson Correlations between the sub-provisions of Corporate Governance

\begin{tabular}{|c|c|c|c|c|}
\hline & Shareholders & $\begin{array}{c}\text { Public } \\
\text { disclosure \& } \\
\text { Transparency }\end{array}$ & Stakeholders & $\begin{array}{l}\text { Board of } \\
\text { Directors }\end{array}$ \\
\hline Shareholders & 1 & 0.4065 & 0.4993 & -0.0628 \\
\hline $\begin{array}{l}\text { Public Disclosure \& } \\
\text { Transparency }\end{array}$ & 0.4065 & 1 & 0.4927 & 0.0336 \\
\hline Stakeholders & 0.4993 & 0.4927 & 1 & 0.0524 \\
\hline Board of Directors & -0.0628 & 0.0336 & 0.0524 & 1 \\
\hline
\end{tabular}

The OLS (ordinary least squares) estimation (Table 2, Panel A) assumes that there is no correlation between explanatory variables and the error term. The BreuschPagan Lagrange multiplier test (Breusch and Pagan, 1980) reveals the presence of heteroscedasticity. In other words, variance of error terms seems to be dependent on the values of the independent variables. Thus, firm-specific effects are important and the OLS results are not efficient. The random effects estimation provides efficient estimates under the assumption that the firm-specific effect is uncorrelated with one or more regressors. If, however, the firm-specific effects are correlated with the regressors, the results of the OLS and random effects are biased and inconsistent (Baltagi, 2005). Then, fixed effects estimator is the consistent estimator. The Hausman chi-square test (Hausman, 1978), comparing fixed effects and random effects estimators rejects the assumption that random effects are not correlated with the regressors $(p<0)$. Therefore, fixed effect GLS (generalized least squares) estimation emerges as the efficient estimator for the equation in which Tobin's $Q$ is the dependent variable.

Table 2: Panel Regressions - Dependent Variable: Tobin's Q

\begin{tabular}{|c|c|c|c|}
\hline & $\begin{array}{c}\text { Panel A } \\
\text { Pooled OLS }\end{array}$ & $\begin{array}{c}\text { Panel B } \\
\text { Firm Fixed Effects } \\
\text { EGLS }\end{array}$ & $\begin{array}{c}\text { Panel C } \\
\text { Firm Random } \\
\text { Effects EGLS }\end{array}$ \\
\hline CGI OVERALL & $0.025245 * * *$ & $0.025363 * * *$ & $0.027455 * * *$ \\
\hline PUBLIC_SHARES & -0.425169 & $0.372141 * *$ & 0.191140 \\
\hline MARKET_LEVERAGE & $-1.522213 * * *$ & $-2.349007 * * *$ & $-2.259964 * * *$ \\
\hline Adjusted $\mathrm{R}^{2}$ & 0.275345 & 0.910738 & 0.319897 \\
\hline $\begin{array}{l}\text { Breusch-Pagan LM test } \\
\text { p-value }\end{array}$ & $\begin{array}{c}63.97 \\
(0.0000)\end{array}$ & & \\
\hline $\begin{array}{l}\text { Hausman } \chi^{2} \text { test } \\
\text { p-value }\end{array}$ & & & $\begin{array}{c}16.54 \\
(0.0009) \\
\end{array}$ \\
\hline
\end{tabular}

Significance: ${ }^{* * *} \mathrm{p}<0.01,{ }^{* *} \mathrm{p}<0.05,{ }^{*} \mathrm{p}<0.10$

Fixed effects estimator, which assumes that differences across firms can be captured by differences in the constant term, exhibits significant coefficient values. The coefficient of CGI_overall is positive 0.025363 and highly significant (Table 2, Panel B), suggesting that, when other independent variables are fixed, 1 point increase in the overall corporate governance rating (out of 100) will result in 0.025363 increase in Tobin's Q of the firm. Increase in the proportion of public shares is also positively reflected to the firm value. However, increase in leverage negatively affects total firm value. Negative relation between the Tobin's Q and leverage is predictable. As the 
market value of equity increases, Tobin's Q also increases. However, market value leverage decreases because of increased equity level.

In the panel where the dependent variable is ROA (Table 3, Panel D), BreuschPagan test again signals that error terms are correlated with explanatory variables, thus OLS estimation is not the efficient estimator. Hausman test suggests that random effects are not correlated with the regressors. However, in that case, all explanatory variables are insignificant (Table 3, Panel F).

Table 3: Panel Regressions - Dependent Variable: ROA (Return on Assets)

\begin{tabular}{|c|c|c|c|}
\hline & $\begin{array}{c}\text { Panel D } \\
\text { Pooled OLS }\end{array}$ & $\begin{array}{c}\text { Panel E } \\
\text { Firm Fixed Effects } \\
\text { EGLS }\end{array}$ & $\begin{array}{c}\text { Panel F } \\
\text { Firm Random } \\
\text { Effects EGLS }\end{array}$ \\
\hline CGI OVERALL & $0.002477 * * *$ & $-0.000655^{*}$ & -0.000499 \\
\hline PUBLIC SHARES & $-0.117194 * * *$ & 0.005971 & -0.050502 \\
\hline MARKET_LEVERAGE & $-0.120761 * * *$ & 0.012120 & -0.086149 \\
\hline Adjusted $\mathrm{R}^{2}$ & 0.124303 & 0.891340 & 0.011947 \\
\hline $\begin{array}{l}\text { Breusch-Pagan LM test } \\
\text { p-value }\end{array}$ & $\begin{array}{c}118.27 \\
(0.0000)\end{array}$ & & \\
\hline $\begin{array}{l}\text { Hausman } \chi^{2} \text { test } \\
\text { p-value }\end{array}$ & & & $\begin{array}{c}4.28 \\
(0.2324)\end{array}$ \\
\hline
\end{tabular}

Significance: ${ }^{* * *} \mathrm{p}<0.01,{ }^{* *} \mathrm{p}<0.05,{ }^{*} \mathrm{p}<0.10$

As Bhagat and Bolton (2008) emphasizes, the relation between corporate governance and performance might be endogenous and results could be biased. When endogenous relation exists between governance and firm performance, it might be necessary to estimate equations by specifying the inter-relationship among the variables using instrumental variables technique. With the help of simultaneous equations framework, we can consider the relationship among corporate governance, performance, capital structure, and ownership structure.

Following equations are simultaneously solved with the anticipated instruments influencing independent variables:

MA BA = f(CGI OVERALL, PUBLIC SHARES, MARKET LEVERAGE, $\left.Z_{1}, \varepsilon_{1}\right)$

Instruments: cgi_overall(-1), public_shares(-1), market_leverage(-1), log(assets), stakeholders,

CGI OVERALL = F (MA BA, PUBLIC SHARES, MARKET LEVERAGE, $\left.Z_{2}, \varepsilon_{2}\right)$

Instruments: ma_ba(-1),public_shares(-1), market_leverage(-1), log(assets), shareholders, stakeholders, book_leverage,

PUBLIC SHARES = $f\left(M A B A_{1}\right.$ CGJ OVERALL, MARKET LEVERAGE, $\left.Z_{3}, \varepsilon_{3}\right)$

Instruments: ma_ba(-1), cgi_overall(-1), market_leverage(-1), log(assets),

fixedassets_assets, shareholder_return,

MARKET LEVERAGE = $f\left(M A B A\right.$, CGI OVERALL, PUBLIC SHARES, $\left.Z_{1}, \varepsilon_{1}\right)$

Instruments: ma_ba(-1), cgi_overall(-1), public_shares(-1), log(assets), ebit_assets, shareholders, stakeholders, 
Instrumental variables allow for consistent estimation when variables on the right-hand side of the equation are correlated with the error terms, in other words, in case of endogenous relationship between the variables. Two-stage least squares (2SLS) handles potential endogeneity problem, and three-stage least squares (3SLS) allows for potential endogeneity and cross-correlation between system-equations (Bhagat and Bolton, 2008).

Table 4: Results of System Equations - Dependent Variable Tobin's Q in Equation 1

\begin{tabular}{|c|c|c|c|}
\hline & OLS & 2SLS & 3SLS \\
\hline $\begin{array}{l}\text { Coefficient of cgi_overall } \\
\text { (eq.1) }\end{array}$ & $0.025245 * * *$ & $0.025732 * * *$ & $0.026919 * * *$ \\
\hline $\begin{array}{l}\text { Coefficient of ma_ba } \\
\text { (eq.2) }\end{array}$ & 0.873528 & 0.639109 & 0.651336 \\
\hline Adjusted $\mathrm{R}^{2} \quad$ Eq.1 & 0.275345 & 0.269552 & 0.279914 \\
\hline Adjusted $\mathrm{R}^{2}$ Eq.2 & 0.166604 & 0.127236 & 0.127508 \\
\hline Adjusted $\mathrm{R}^{2}$ Eq.3 & 0.182845 & 0.148412 & 0.117373 \\
\hline Adjusted R ${ }^{2}$ Eq.4 & 0.213201 & 0.217081 & 0.209245 \\
\hline
\end{tabular}

Significance: $* * * \mathrm{p}<0.01,{ }^{* *} \mathrm{p}<0.05,{ }^{*} \mathrm{p}<0.10$

Estimated coefficients of cgi_overall in system equations are very close to coefficients estimated with the fixed effects estimator and they are again highly significant (Table 4). Different estimators revealing similar results confirm the robust positive relationship between corporate governance rating score and Tobin's Q. However, the coefficient of Tobin's Q (ma_ba) reveals that vice versa relation is not verifiable between the two. Estimated coefficients of Tobin's Q are insignificant in all system estimations. Thus, the causal effect of market performance (Tobin's Q) on corporate governance rating is not confirmed. Equations simultaneously solved confirm only one-way relation between market performance and corporate governance rating. Results suggests that $1 \%$ improvement in corporate governance rating score is associated with around 2.5\% improvement in firm performance measured by Tobin's Q, when other variables are held constant. The results are consistent with Gompers et al. (2003), Bebchuck et al. (2009) and Bhagat and Bolton (2008) although they have adopted different methodology to score governance of firms.

Table 5: Results of System Equations - Dependent Variable ROA in Equation 1

\begin{tabular}{|c|c|c|c|}
\hline & OLS & $2 \mathrm{SLS}$ & $3 \mathrm{SLS}$ \\
\hline $\begin{array}{l}\text { Coefficient of cgi_overall } \\
\text { (eq.1) }\end{array}$ & $0.002477 * * *$ & $0.002660 * * *$ & $0.002858 * * *$ \\
\hline $\begin{array}{l}\text { Coefficient of ebit_assets } \\
\text { (eq.2) }\end{array}$ & -5.079652 & -7.817447 & -7.019589 \\
\hline Adjusted R ${ }^{2}$ Eq.1 & 0.124303 & 0.154579 & 0.138545 \\
\hline Adjusted $\mathrm{R}^{2} \quad$ Eq.2 & 0.164426 & 0.101464 & 0.104444 \\
\hline Adjusted $\mathrm{R}^{2}$ Eq.3 & 0.234849 & 0.190588 & 0.164325 \\
\hline Adjusted R ${ }^{2}$ Eq.4 & 0.049955 & 0.087794 & 0.073578 \\
\hline
\end{tabular}

Significance: $* * * p<0.01, * * p<0.05, * p<0.10$

Panel D in Table 3, implies a positive relationship between the governance rating and operating performance (ROA). However, error terms are not i.i.d. (identically, independently distributed), and random effects model (Panel F) does not indicate a significant relation between the two. System equations result (Table 5) 
suggests a positive and significant one-way relation between corporate governance rating and firm's operating performance measured by ROA. 1\% improvement in corporate governance score results in roughly $0.25 \%$ increase in ROA.

Table 6: Effect of Sub-provisions of Corporate Governance Rating on Tobin's Q

\begin{tabular}{|c|c|c|c|}
\hline & OLS & $\begin{array}{l}\text { Fixed Effects } \\
\text { EGLS }\end{array}$ & $\begin{array}{c}\text { Random Effects } \\
\text { EGLS }\end{array}$ \\
\hline SHAREHOLDERS & $0.025710 * * *$ & $0.021518 * * *$ & 0.021557 \\
\hline PUBLIC_SHARES & -0.313575 & 0.297460 & 0.067841 \\
\hline MARKET_LEVERAGE & $-1.631099 * * *$ & $-2.432788 * * *$ & -2.330512 \\
\hline Adjusted $\mathrm{R}^{2}$ & 0.234116 & 0.908230 & 0.299643 \\
\hline $\begin{array}{l}\text { Breusch-Pagan LM test } \\
\text { p-value }\end{array}$ & $\begin{array}{c}77.86 \\
(0.0000)\end{array}$ & & \\
\hline $\begin{array}{l}\text { Hausman } \chi^{2} \text { test } \\
\text { p-value }\end{array}$ & & & $\begin{array}{c}16.27 \\
0.0010\end{array}$ \\
\hline TRANSPARENCY & $0.023818 * * *$ & $0.015578 * * *$ & 0.011213 \\
\hline PUBLIC_SHARES & -0.468380 & 0.093096 & -0.185818 \\
\hline MARKET_LEVERAGE & $-1.420972 * * *$ & $-2.343588 * * *$ & $-2.219224 * * *$ \\
\hline Adjusted $\mathrm{R}^{2}$ & 0.248122 & 0.923943 & 0.268126 \\
\hline $\begin{array}{l}\text { Breusch-Pagan LM test } \\
\text { p-value }\end{array}$ & $\begin{array}{c}58.55 \\
(0.0000)\end{array}$ & & \\
\hline $\begin{array}{l}\text { Hausman } \chi^{2} \text { test } \\
\text { p-value }\end{array}$ & & & $\begin{array}{c}11.48 \\
0.0094\end{array}$ \\
\hline STAKEHOLDERS & $0.023642 * * *$ & $0.003182 * * *$ & $0.024312 * * *$ \\
\hline PUBLIC_SHARES & -0.302573 & 0.168151 & 0.171564 \\
\hline MARKET_LEVERAGE & $-1.539960 * * *$ & $0.136217 * * *$ & $-2.198777 * * *$ \\
\hline Adjusted $\mathrm{R}^{2}$ & 0.318964 & 0.890543 & 0.299661 \\
\hline $\begin{array}{l}\text { Breusch-Pagan LM test } \\
\text { p-value }\end{array}$ & $\begin{array}{c}44.51 \\
(0.0000)\end{array}$ & & \\
\hline $\begin{array}{l}\text { Hausman } \\
\text { p-value }\end{array}$ & & & $\begin{array}{c}10.35 \\
0.0158\end{array}$ \\
\hline BOD & 0.000122 & -0.0000117 & -0.00000373 \\
\hline PUBLIC_SHARES & $2.571946^{* * *}$ & -0.174043 & -0.347409 \\
\hline MARKET_LEVERAGE & 0.959130 & $-2.313936^{* * *}$ & $-2.243263 * * *$ \\
\hline Adjusted $\mathrm{R}^{2}$ & -1.240331 & 0.909509 & 0.263290 \\
\hline $\begin{array}{l}\text { Breusch-Pagan LM test } \\
\text { p-value }\end{array}$ & $\begin{array}{l}197.81 \\
(0.0000)\end{array}$ & & \\
\hline $\begin{array}{l}\text { Hausman } \chi^{2} \text { test } \\
\text { p-value }\end{array}$ & & & $\begin{array}{c}9.20 \\
0.0267 \\
\end{array}$ \\
\hline
\end{tabular}

Significance: ${ }^{* * *} \mathrm{p}<0.01,{ }^{* *} \mathrm{p}<0.05,{ }^{*} \mathrm{p}<0.10$ 
Table 6 gives panel estimations for the effect of sub-provisions of corporate governance rating on Tobin's Q. In the panel estimations, one sub-provisional score replaced overall rating score in each estimation.

Breusch-Pagan tests (Breusch and Pagan, 1980) imply the problem heteroscedasticity $(p<0)$ in all panel regressions. Thus, ordinary least squares (OLS) is not appropriate. Besides, Hausman chi-square test (Hausman, 1978) which assesses the orthogonality of random effects and the regressors, suggests that random effects are correlated with the regressors except in transparency regression. Thus, fixed effects estimator is the fitting estimator in all regressions except in transparency, where random effects model is preferred to fixed effects model.

Rating scores on shareholders, public disclosure/transparency and stakeholders seem to have positive impact on firm's market value measured by Tobin's Q. Board structure appears to be irrelevant on determination of firm value. On the other hand, similar to previous estimations with the overall governance rating, the effect of ownership structure (measured by proportion of public shares) on value is not robust.

\section{Conclusion}

Corporate governance defines relationships among management, board, shareholders, and other stakeholders. Effective corporate governance is expected to facilitate finding investors, and eventually result in decreased cost of capital, as well as disclosing and preventing agency problems. As corporate governance is expected to decrease agency costs and cost of capital of the firm, a better corporate governance arrangement might be expected to translate into higher shareholder return and firm performance.

The study analyzed the empirical relationship between corporate governance ratings of firms and their performance with a sample from Borsa Istanbul (BIST). The study verified the significant one-way positive relation between corporate governance score and stock market performance. It is found that $1 \%$ improvement in the overall corporate governance rating resulted in around $2.5 \%$ increase in market performance measured by Tobin's Q. A significant but weaker one-way positive relation between corporate governance score and operating performance is also observed. It is verified that $1 \%$ increase in overall corporate governance rating results in around $0.25 \%$ improvement in operating performance (measured by ROA). As the results could have been affected by endogeneity bias, the robustness of results is confirmed by an estimation which takes into account the inter-relationships among corporate governance, corporate performance, corporate capital structure, and corporate ownership structure as suggested by Bhagat and Bolton (2008). Simultaneous equation estimations with instrumental variables (IV) using 2SLS and 3SLS demonstrated similar results.

It is also found that three of the four sub-criteria of corporate governance ratings are highly correlated. The correlations among shareholders, stakeholders and public disclosure and transparency are all above $40 \%$. However, rating on board of directors sub-provision seems to be totally un-related with other sub-provisions of corporate governance rating. It is discovered that shareholders, public disclosure and transparency, stakeholders provisions positively affect market performance. However, board of directors provision is immaterial in determination of market performance. 


\section{References}

Aydin, A. D., Ozcan, A. (2015). Corporate Governance and Firm Performance: Recent Evidence from Borsa Istanbul (BIST) Corporate Governance Index (XKURY). Research Journal of Finance and Accounting, Vol.6, No.14, pp. 198-204.

Baltagi, B., H., (2005). Econometric Analysis of Panel Data. John Wiley \& Sons Ltd.

Bauer, R., Frijns, B., Otten, R., \& Tourani-Rad, A. (2008). The impact of corporate governance on corporate performance: Evidence from Japan. Pacific-Basin Finance Journal, 16(3), 236-251.

Bebchuk, L., Cohen, A., \& Ferrell, A. (2009). What matters in corporate governance?. Review of Financial studies, 22(2), 783-827.

Bhagat, S., \& Bolton, B. (2008). Corporate Governance and Firm Performance. Journal of Corporate Finance, 14(3), 257-273.

Bhagat, S., Bolton, B., \& Romano, R. (2008). The promise and peril of corporate governance indices. Columbia Law Review, 1803-1882.

Black, B. S., Jang, H., \& Kim, W. (2006a). Does corporate governance predict firms' market values? Evidence from Korea. Journal of Law, Economics, and Organization, 22(2), 366-413.

Black, B. S., Love, I., \& Rachinsky, A. (2006b). Corporate governance indices and firms' market values: Time series evidence from Russia. Emerging Markets Review, 7(4), 361-379. 2005 olan

Breusch, T. S., \& Pagan, A. R. (1980). The Lagrange multiplier test and its applications to model specification in econometrics. The Review of Economic Studies, 47(1), 239-253.

Brown, L. D., \& Caylor, M. L. (2006). Corporate governance and firm valuation. Journal of accounting and public policy, 25(4), 409-434.

CMB. (2005). Corporate Governance Principles. First issued: July 2003 Amended second issuance date: February 2005. www.spk.gov.tr.

Drobetz, W., Schillhofer, A., \& Zimmermann, H. (2004). Corporate Governance and Expected Stock Returns: Evidence from Germany. European Financial Management, 10(2), 267-293.

Ege, İ., Topaloğlu, E. E., Özyamanoğlu, M. (2013). Finansal Performance ile Kurumsal Yönetim Notları Arasındaki İlişki: BIST Üzerine Bir Uygulama. Akademik Araştırmalar ve Çalışmalar Dergisi, 3(9), 100-117.

Erdoğan, M. And Öztürk, M. S. (2016). Kurumsal Yönetim Endeksinde Yer Alan İşletmelerin Performansına Etki Eden Finansal Oranların İncelenmesi. Muhasebe Bilim Dünyası Dergisi. 18(1), 707-725.

Gompers, P. A., Ishii, J., L., Metrick, A. (2003). Corporate Governance and Equity Prices. Quarterly Journal of Economics. 118(1), 107-155.

Hasbrouck, J. (1993). Assessing the quality of a security market: A new approach to transaction-cost measurement. Review of Financial Studies, 6(1), 191-212. 
Hausman, J. A. (1978). Specification tests in econometrics. Econometrica: Journal of the Econometric Society, 1251-1271.

Kara, E., Erdur, A. D., and Karabiyık, L. (2015). Effects of Corporate Governance Level On The Financial Performance Of Companies: A Research On BIST Corporate Governance Index (XKURY). Ege Academic Review. 15(2), 265-274.

Klapper, L.F. and I. Love. "Corporate Governance, Investor Protection, and Performance in Emerging Markets," Policy Research Working Papers \#2818, World Bank (2002).

Kula, V., Baykut, E. (2015). Does Better Corporate Governance Ratings Lead to Higher Market Value? An Empirical Investigation of BIST XKURY Listed Companies. Electronic Journal of Vocational Colleges. December, 47-54.

Lee, C., Chung, K. H., \& Yang, S. (2015). Corporate governance and the informational efficiency of prices. Financial Management.

Lehmann, E., \& Weigand, J. (2000). Does the governed corporation perform better? Governance structures and corporate performance in Germany. European Finance Review, 4(2), 157-195.

OECD (2015), G20/OECD Principles of Corporate Governance, OECD Publishing, Paris. (Retrieved from http://dx.doi.org/10.1787/9789264236882-en on Nov.2, 2016)

Sakarya, Ş. (2011). İMKB Kurumsal Yönetim Kapsamındaki Şirketlerin Kurumsal Yönetim Derecelendirme Notu ve Hisse Senedi Getirileri Arasındaki İlişkinin Olay Çalışması (Event Study) Yöntemi ile Analizi. ZKÜ Sosyal Bilimler Dergisi. 7(13), 147-162.

Silva, A. L. C. D., \& Leal, R. P. C. (2005). Corporate governance index, firm valuation and performance in Brazil. Brazilian Review of Finance, 3(1), 1-18.

Yenice, S., Dölen, T. İMKB'de İşlem Gören Firmaların Kurumsal YÖnetim İlkelerine Uyumunun Firma Değeri Üzerindeki Etkisi. Uluslararası Yönetim İktisat ve İşletme Dergisi. 9(19), 199-213.

http://www.borsaistanbul.com/endeksler/bist-pay-endeksleri/kurumsal-yonetim-endeksi (Retrieved on date Nov.16, 2016) 